\title{
VOTE OF THANKS TO THE ORGANISERS
}

\author{
GEORGE B. FIELD
}

Mr Chairman and Participants in the Symposium.

When I heard that this Symposium was to be held in Poland, I did not see right away why this small country had been chosen, when such a large number of scientists had to be accommodated.

When I came I discovered the reason. What other country and what other people could have been so friendly and helpful, even when deluged by visitors from both East and West, all chattering away in their native tongues? As a participant from America, I offer my sincere thanks.

The unfailing graciousness of our hosts, even under trying circumstances, was noted by all of us. One way or another all problems were disposed of usually by one of our hosts speaking in our own native tongues.

We are particularly appreciative of the work of Prof. Rudnicki, Dr Skolimowska and their staffs who were constantly available to assist us. All of us were aware of the excellent arrangements here at the University. Best of all, we will carry home with us strong impressions of the cultural life of Poland, as it came to us in concerts and evening strolls in the beautiful city of Cracow.

Finally, let me applaud the efforts of our indomitable organiser, Prof. Zel'dovich, who, having arranged for the programme at this Symposium, went on to stimulate discussion of every contribution and to summarise for us what was happening even in specialities far from his own. Of course much of the credit for the fine programme goes to his organising committee but I would single out for thanks Dr Longair who, I suspect, pulled many strings behind the scenes to make sure things came out alright.

The meeting turned out to be not so much a 'confrontation' as a 'condensation'. At last, a thinly-spread galaxy of experts was brought together to form a single unit capable of working together more constructively toward an understanding of the Universe. For this, all of us are grateful to the organisers and to our hosts. 